\title{
The Role of Doctoral Study in the Professional Path of Academics
}

\section{Yanyan Li, Jana Poláchová Vašt’atková}

\begin{abstract}
To prepare the next generation of academics is considered the primary function of doctoral education. This study attempts to identify the role of doctoral study on the path of academics. The data were collected by the in-depth interview of Ph.D. graduates who had achieved their doctor degree of education successfully at Palacký University Olomouc in the past decade. The life stories of seven interviewees were included in analyzing by coding process. Six categories were generalized under three themes based on the grounded theory.
\end{abstract}

Keywords: doctoral study of education, professional path, Ph.D. graduates, life stories, grounded theory

\section{Introduction}

The doctoral degree is necessarily needed for most of the academic positions at the university or research institutions. Although there are a range of roles for Ph.D. graduates based on the doctoral study programme of education, the academic is the primary pursuit. Graduate education is considered as the period of "anticipatory socialization" (Van Maanen, 1983). The socialization that occurs during graduate education contrib- 
utes to how faculty members understand their work and assume their professional roles (Austin \& McDaniels, 2002). The Ph.D. students are experiencing several socialization processes simultaneously: socialization to the role of graduate student, socialization to the academic life and the academic profession, and socialization to a specific discipline or field (Staton \& Darling, 1989). Through formal and informal opportunities, the socialization occurs as doctoral students learn knowledge and skills required for work in the field, interact with faculty and student peers, and integrate into the activities of their fields (Weidman \& Twale \& Stein, 2001).

However, the study experience is not planned in a way that specifically prepares for professional development of identity. On the one hand, doctoral education is characterized by a lack of systematically and developmentally organized preparation experiences (Austin \& McDaniels, 2006). On the other hand, the Ph.D. students fail to receive feedback to clearly explain their performance (Lovitts, 2004). The nature of academic career is lack of attention in the process of Ph.D. study (Golde \& Dore, 2001). Therefore, the previous research findings raised the essential concern about the preparation process and efficiency of doctoral study on the path to the professoriat for Ph.D. students. However, qualitative, ethnographic studies, especially ongoing and longitudinal investigations, have been overlooked in the field of graduate education research (Malaney, 1988). Future research on graduate education would benefit from the inclusion of a variety of voices and perspectives both inside and outside of higher education (Wulff \& Austin, 2004). This study presents the role of doctoral study on Ph.D. graduates' career path of academics with specific attention on the subject of education.

As the aim of the doctoral study programme of education at Palacký University, this programme is to prepare qualified specialists of scientific research and independent creative activities to solve theoretical and practical problems in the field of education. And the Ph.D. graduates might work as qualified teachers at universities as independent creative workers in educational research, etc. It is obvious that the focus of the doctoral study is not only to improve the knowledge of methodology but also on extension the theoretical outlook in the field of educational research. Therefore, the mastery of knowledge and ability is essentially centralized as the cognitive domain as well as the value of professionalism as the emotional domain on the path to the academics. In the previous publication of the author, the emotional impact of doctoral study of education was already deeply investigated especially on the professional value and self-cognition of Ph.D. graduates (Li, 2014). In the article, three identity effects brought from the doctoral study of education are listed as the cognition of education as a subject of science, identification of themselves as an educational researcher, and confirmation of doing research as a life style in Ph.D. graduates' academic career. And the author emphasized that these three aspects are connected and interacted with each other through the proceeding of doctoral study. Hence, the knowledge and ability were concentrated on in this study which was interpreted from the doctoral study of education by the Ph.D. 
graduates on the path to the academics. Moreover, the theory was conducted on the basis of these two domains including the cognitive and emotional impact of doctoral study on the Ph.D. graduates' academic path.

\section{Methodology}

The study addresses Ph.D. students' experience of the doctoral study programme of education particularly on their perspective of the role in their path to the academics. Two research questions are mainly focused on. What was learned cognitively by the Ph.D. graduates from their doctoral study? What is the impact of the doctoral study on the Ph.D. graduates' professional path to the academics?

The respondents of this study are Ph.D. graduates who finished the doctoral study programme of education from Palacký University Olomouc during the last ten years. As English speakers with C1 level, ten graduates were invited and seven of them were interviewed. Five out of seven of them are currently employed as academic staff at the university and the other two respondents are researchers at other educational institutions in the Czech Republic.

The specific scheme follows seven stages of an interviewing process which includes thermalizing, designing, interviewing, transcribing, analyzing, verifying and reporting (Kvale, 1996). The respondents were told clearly the purpose and process of the interview firstly. The interview outline was settled by a set of topics based on the CIPO (Context-Inputs-Process-Outputs) model (Scheerens, 1990) and been divided into three areas, the experience before the doctoral study of education, the experience during the doctoral study of education and the experience after the doctoral study of education, with differences brought from the doctoral study process. Based on the framework of three periods of experience, the lightly-structured outline of inquiry was generalized in the depth interview (Wengraf, 2001, pp. 111-113). The whole interview was recorded and transcribed then from taped into the written form. The experience and perception of the Ph.D. graduates is generalized as their life stories.

On the basis of the grounded theory, the analysis process was inductively developed (Glaster \& Strauss, 2006; Pidgeon \& Henwood, 2004). Firstly, the transcribed materials of each graduate were analyzed initially with open coding by two independent and experienced researchers in the first circle and discussed with each other in the second circle. Two analytic procedures are fundamental for generalization of the concepts in the coding process, including the "making of comparisons" and "asking of questions" (Strauss \& Corbin, 1990, pp. 62-63). The categories were developed in terms of their properties and dimensions to recognize the relationship between the categories and subcategories systematically. Secondly, axial coding was developed in an organizing scheme including conditions, actions/interactions, and consequences (Strauss \& Corbin, 
1998, p. 128). However, the frame may extend or limit the vision (Chamaz, 2006, p. 61). By means of the paradigm model, the subcategories are linked into a category in a set of relationships above. Thirdly, the grounded theory was built upon the core categories at a higher, more abstract level of analysis by selective coding. A new life story of the Ph.D. graduates of education is recreated with centralized concern of a general descriptive overview of the study experience (Goodley, et al., 2004). The theory was laid out with the foundation of the combined relationship between categories as well as their properties and dimensions.

\section{Findings}

The researchers intended to uncover the experience of the Ph.D. graduates during their doctoral studies and after graduation. Being analyzed by open coding in the first circle, axial coding in the second circle and selective coding in the third circle, the categories were generalized as three main activities including "learning methodology of research", "teaching basic subjects of education" and "research for the dissertation" to show the process of learning in the doctoral study programme of education. Furthermore, the model of impact of doctoral study on the professional path of academics is formulated in three themes including "theoretical learning", "pedagogical practice", and "academic research" under two domains of "professional ability" and "scientific disposition".

\subsection{Learning process in the doctoral study programme}

The experience of studying in the doctoral study programme is generalized in the following chart to show the result of analyzing. The subcategories are related by the scheme including "conditions", "action/interactions" and "categories". And the subcategories are concluded through the coding process of the life stories especially on the studying experience of the doctoral programme of education (see Chart 1). Additionally, the content of interview will be written in italic type in the following explanation of the scheme. 


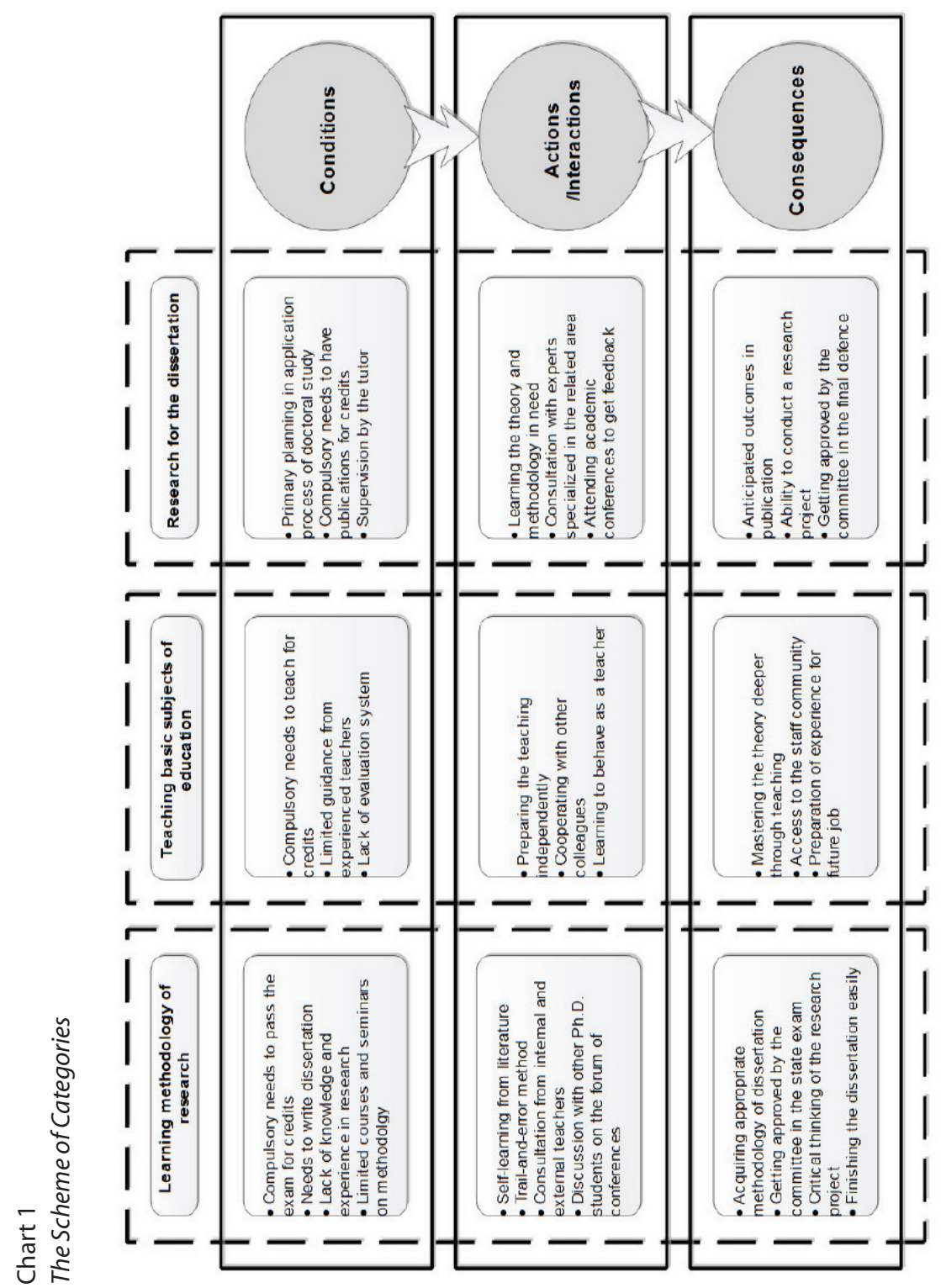




\section{Category 1: Learning methodology of research}

During the studying of the doctoral programme of education, there are several exams to pass for each of the Ph.D. students. One of them is "research methodology". "The most difficult one was methodology. But I think the most important thing we did was reading a lot of books for what I need for my study." The study is concentrated on and guided by the needs of dissertation. As the lack of knowledge and experience of research, it is the hardest exam for the students in general. "It would be much easier if I knew something in advance, because I had to spend a lot of time studying in the library."

Although some courses are provided in the study programme, it seems to be insufficient for them. "We didn't have much methodology as Ph.D. students. In the doctoral studies, there was only a one-semester methodology course. The courses were held once in fifteen days. That's all." The seminar helps simultaneously. "We had some seminars on research methodology and one subject called 'Methodology.' There was a person who finally came to you and said that you were not good and needed to think more about it. It was the best and only one we had about the methodology. That was the exact date when I started to go the library and read books to find how to do it about methodology actually." However, the students have to study by their own most of the time. "The examiner always only gave us some basic information of subjects. It was up to us if we would like to learn more or not." And the way of learning turns to be self-learning and the trial-anderror method. "We really had to look for books to read and learn by ourselves. I think $80 \%$ of what I learned about methodology was from books. I thought all of us had little knowledge about methodology, so we made a lot of mistakes in our research. We tried every way we found and gave up the wrong ones gradually. That's how we found the right one actually. It was not an easy job. I changed my dissertation at least twice completely."

In addition to independent learning, the Ph.D. students consult other internal and external teachers specialized in the related areas as well. "I tried to discuss my project with other teachers of the institute. And they helped me indeed. I always tried to ask them if they had time to discuss with me and they did... So I had to try to contact people at another university and asked help from some people teaching there who focused more on ... But the teachers working there didn't really like to help me and they just asked me to read this book and that book. And that's all." The opportunity to attend the academic conference is also a way to get feedback from the experts and other students. "We had to go to some conferences. They gave me a lot of feedback but without much information or positive suggestion. They just told me that it could be good or bad but they never know, and it could be good but you will find more things if you think more about it. I think they never tell you directly their opinion about the work. And there were usually seminars for Ph.D. students at the conference. It was great."

The mastering of methodology increases in proceeding ways of learning. "I was quite scared about my study at the third time. I was afraid that it would be bad again because it was the final decision. I would stop my studies if it was bad again. However, they said it 
was great on my state exam. I think it was quite easy to answer their questions for me." It is verified to be a positive end of the learning process at least for the dissertation. "The last year's study and the final defence of my dissertation were quite easy for me to find the right way and do the research as I planned."

\section{Category 2: Teaching basic subjects of education}

For the second category of "teaching basic subjects of education", it is another compulsory task of the Ph.D. students in the doctoral programme of education. "And we had some task to teach courses for bachelor and master students at the faculty as Ph.D. students. I taught master students of Pedagogy for a whole semester and some other subjects for two hours sometimes". "It was part of the deal to receive the scholarship I think. All of the Ph.D. students taught at least one seminar on other subjects." In preparing their teaching, the guidance is provided by an experienced teacher of the specific subject. "In teaching the statistics, the professor gave us the syllabus and we didn't change so much. He told us what to teach and gave us materials he was using in teaching. We used the book written by him. We prepared it each week with his guidance. And we also tested the students at the end of the semester to get passed or failed." However, there is not always such guidance. "I prepared the teaching, taught what I wanted, and examined them by myself. Everything was fresh for me so that I had to find a topic, collected all of the information of it and prepared the presentation even I had learned it before." It is a time-consuming task for Ph.D. students. "We tried to do what he would do because we didn't have time or experience or knowledge to prepare anything else. So we were rather happy that he gave us all the materials to teach. The teaching was once a week, maybe a 50-minutes lesson. I have to spend at least 50 or longer to prepare it."

An important change of self-cognition happens during the teaching experience. "In these three years'study, l experienced a big change of the role from a student to a teacher at the university at least in my mind. At that moment, I knew I had to teach as a Ph.D. student. It was a big problem for me to change my role from a student to a teacher, because I had to be act like a teacher. I was a student as well as a teacher in a period. Although it took a long time to learn how to behave as a teacher, I learned when I started to teach. I started to feel that I was a teacher at the university when I studied the doctoral programme. The experience made you feel like a teacher." It becomes a prior practice for the future job. "I think it was necessary to teach at the university as a Ph.D. student studying Pedagogy, because it was only good to have doctoral studies when you wanted to work at the university. So you should try teaching as well. I think we should have some competency in teaching but there were always problems because it doesn't mean you are a good teacher when you are a good researcher."

However, the result of teaching is lack of evaluation in the doctoral study programme of education as it has not been concluded in the assessment system of the achievement of the Ph.D. students. "In our programme, we had to prove that we were 
good in research by publication and dissertation. But you didn't have to prove that you were a good teacher without any evaluation system in the programme. Nobody came to my class and evaluated it. I could do what I want. Nobody knows what you do there, even if you did nothing. There was no evaluation system of teachers' performance in teaching. I think the students were upset sometimes because they were always expecting a professional teacher in the class. But we never knew whether we were good or not. We should be qualified and it is extremely important to have good teachers at the university in my opinion."

\section{Category 3: Research for the dissertation}

For the third category of "research for the dissertation", the process of connection is presented from the condition of "primary planning in application process of doctoral study" firstly. "I wrote a plan of my thesis with the aims of my research, what I was trying to do, why it was important to do this research, the theory of it and other aspects. I sent it to the commission. I think they were glad to see my project what was something new and interesting for them. It was an original and new topic for them. They believed that I had to change it because there were a lot of problems in the proposal that was not perfect. But they thought I could make it better. Finally they accepted me easily because it was good to give me a chance to do it and my supervisor had accepted me as her student yet."

There are some basic subjects of education that have to be examined compulsorily and optionally besides "research methodology", such as the "philosophy of education", "psychology of education", and so on. The Ph.D. students learned the theory and methodology which is related to their own project of dissertation from diverse perspective of these subjects. Additionally, the publication of research outcomes is compulsorily required to get the credit each school year. "The requirement of publication pushed me to publish works but I would still try to do that even without the requirement. There was no problem for me to finish all of the tasks in publication because I wrote them as my free time activities. I enjoyed it. I think it's necessary to get articles published in journals which would provide some evidence to the academic committee to make the judgment of your research. It was also important for the university that would get money for the publication. For the students, you could really learn how to write academic articles correctly before your dissertation." It is important for students to do research and get it published under the guidance of a supervisor. "I always asked my supervisor where to send the article when I finished. That's what we discussed mostly about." "I always sent my articles to my supervisor to ask for her comment. And she usually gave me some suggestions and modified my articles." There is also research on which they cooperated with their supervisors. "I had a cooperated article with my supervisor which connected her dissertation and my thesis in the master programme together. We used the same questionnaire and I just combined the result from her schools and mine. It was quite easy to do that because the data were similar thanks to the same questionnaire." 


\subsection{Impact of the doctoral study on professional path of academics}

Based on the life stories generalized preliminarily from the experience of Ph.D. graduates, two domains are categorized under three themes of the doctoral study of education. On the one hand, the domain of professional ability is the visible identity in which concludes the knowledge and skill achieved from the doctoral study. On the other hand, the domain of scientific disposition is the invisible identity including the character and value acquired from the doctoral study. Meanwhile, three themes are specifically the responsibilities of the Ph.D. students involved in the doctoral study programme of education. Firstly, the learning responsibility is basically required through the process especially on self-learning. Secondly, the teaching experience is necessarily needed within the study programme as Ph.D. students as well as university teachers. Thirdly, the academic research is essentially concentrated on conducting the dissertation. The theory is provided as follows to show the impact of the doctoral study programme of education on the perspective of the Ph.D. graduates.

\section{Chart 2}

Model of Impact on the Professional Path of Academics from the Doctoral Study of Education

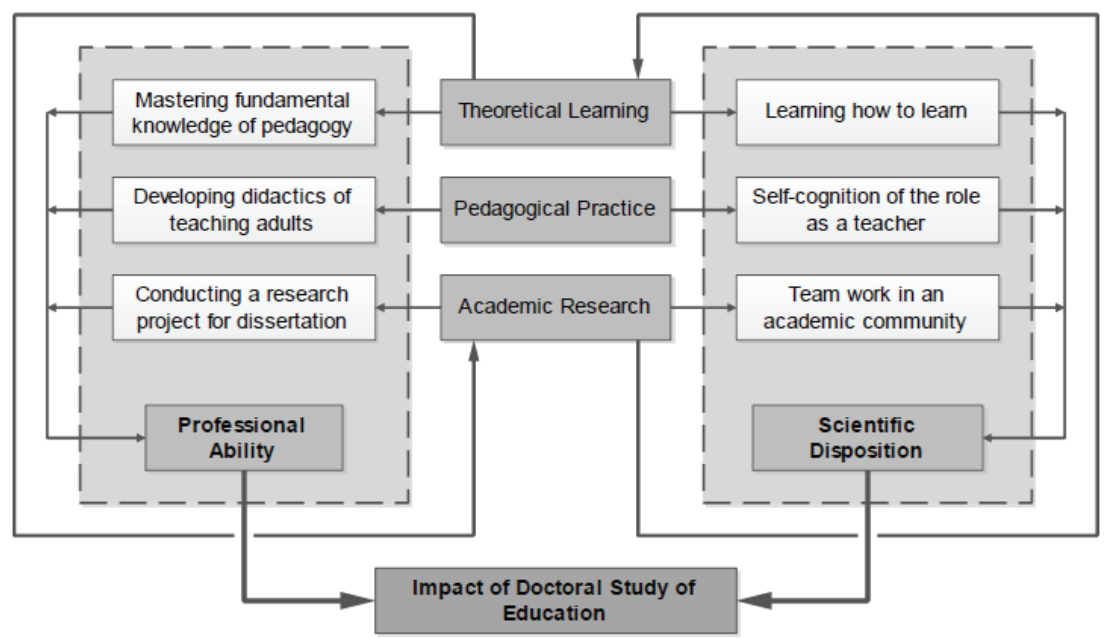

There are two distinct stages in most doctoral programmes: coursework and dissertation (West et al., 2011). For the doctoral study programme of education, there is 
another important process involved which is the teaching experience. In processing the three responsibilities of learning, teaching and writing the dissertation, there are three contents of study including the "theoretical learning", "pedagogical practice" and "academic research" in the doctoral study programme of education. Under the theme of "theoretical learning", the professional ability of "mastering fundamental knowledge of pedagogy" is one essential category in evaluation of the impact of the doctoral study while the scientific disposition of "learning how to learn" is the other identity. Under the theme of "pedagogical practice", the categories are the ability of "developing didactics of teaching adults" and the disposition of "self-cognition of the role as a teacher". Besides, the criteria of evaluation are concerned with the ability of "conducting a research project for dissertation" and spiritual character of "team work in an academic community".

The two domains show the visible and invisible identities brought from the doctoral study programme of education to the Ph.D. students and then reflected in their career path to the professoriate. It is the advanced period of evaluation the impact of doctoral study programme on the perspective of the Ph.D. graduates compared with the concept of "academic match" defined by Hoskins and Goldberg which is compared to the correspondence between "student goals and reasons for pursuing the degree" and "the program focus and the curriculum" (2005, p. 183). It is also proved to be an appropriate way to evaluation of the doctoral programme of education.

\section{Discussion}

In the previous research, the Ph.D. students of education are believed that they have little formal training in education research before they started their doctorate, with their educational background in other disciplines or on educational practice (Labaree, 2003). In this case, the concept of "doctors of education" is defined as stewards of both the field of study and the enterprise of education (Richardson, 2003). This study is consistent with the assumption that the doctorate is primarily for research training. The doctoral candidates should be expected to do creative scholarly work and outline what they feel are the psychological, theoretical-methodological, and institutional contexts required for creative work (Bargar \& Duncan, 1986). Centralized by the aim of preparing the future academics, the knowledge, ability and value are supposed to be devoted in cultivating the Ph.D. students as well as the educational researchers.

The key objective was identified by three core activities including learning, teaching and research. In each of these three responsibilities, the significance was emphasized on learning of research methodology, teaching of basic subjects of education, and research for their dissertations based on the life stories of Ph.D. graduates. Therefore, the process of learning in the doctoral study programme of education was explained from the "condition", "action/interaction" and "consequences" specifically during the 
"learning methodology of research", "teaching basic subjects of education" and "research for the dissertation". Firstly, "learning methodology of research" is one of the most significant parts of the doctoral training process. The emerging literature on preparing doctoral students in education emphasized methodological sophistication as the key to improving education research. Based on a collection of anecdotes and experiences, simplistic approaches to methodology hinder deep understanding of what it means to make and justify a claim about educational phenomena (Schoenfeld, 1999). Secondly, doctoral persistence increases within the programmes that recognize the challenges associated with transitioning from structured coursework to unstructured dissertation writing by building a connection between coursework and skills needed to execute the dissertation (de Valero, 2001; Spaulding, L. S. \& Rockinson-Szapkiw, A. J., 2012). Mullins and Kiley found that for examiners there was a tacit link between candidates' knowledge of the field and their ability to do substantive, well-justified research (2002). Back to the basic assumption of this study, the doctoral dissertation is the capstone to formal academic training of the doctoral study programme of education. There is an emerging consensus that the perceived lack of quality in education research stems from problems with doctoral preparation. And it is essential to improve the quality of doctoral preparation by increasing the efficiency of connection and transformation from the learning activities to the research outcomes.

As a conclusion, the doctoral education is a key means of preparation of academics. This study suggests criteria and formulates a model to evaluate the impact of the doctoral study of education and reports the result that examined the perspective of the Ph.D. graduates of education at Palacký UniversityPalacký University Olomouc. It turned out that the Ph.D. students are required to develop deep understanding of pedagogy as a discipline, to recognize their role as teachers as well as researchers. And the self-cognition process prepares the Ph.D. students on the way to be the academics in balancing the responsibilities of teaching, research and others. Based on the empirical research, the impact of the doctoral study of education is formulated by means of six major and interrelated categories which significantly influenced the professional path of the Ph.D. graduates: mastering fundamental knowledge of pedagogy, developing didactics of teaching adults, conducting a research project for dissertation, learning how to learn, self-cognition of the role as a teacher, team work in an academic community. The first three categories are the criteria of professional ability while the others are the criteria of scientific disposition. The impact of the doctoral study of education is evaluated by these two domains under three themes as the conclusion. In the following research, the model will be the fundamental criteria in evaluation the perspective of other stakeholders involved in the doctoral study programme of education. The longitude interview of the Ph.D. graduates is expected to verify and modify the model in the future research. 


\section{References}

Austin, A. E. \& McDaniels, M. (2002). Preparing the next generation of faculty: graduate education as socialization to the academic career. The journal of higher education, 73(2), 94-122.

Austin, A. E. \& McDaniels, M. (2006). Preparing the professoriate of the future: Graduate student socialization for faculty roles. In Smart J. C. (Ed.), Higher education: handbook of theory and research, Vol. XXI, pp. 397-456. Netherlands: Springer.

Bargar, R. R. \& Duncan, J. K. (1986). Creativity in doctoral research: a reasonable expectation? The Educational Forum, 51(1), 33-43.

Chamaz, K. (2006). Constructing grounded theory: a practical guide through qualitative analysis. Thousand Oaks, California: Sage Publications, Inc.

de Valero, F. Y. (2001). Departmental factors affecting time-to-degree and completion rates of doctoral students at one land-grant research institution. The Journal of Higher Education, 72(3), 341-367.

Glaser, B. G. \& Strauss, A. L. (2006). The discovery of grounded theory: strategies for qualitative research. New Jersey: Aldine Transaction Publishers.

Golde, C. M. \& Dore, M. (2001). At cross purposes: what the experiences of today's doctoral students reveal about doctoral education. Philadelphia, PA: Pew Charitable Trusts.

Goodley, D., Lawthom, R., Clough, P. \& Moore, M. (2004). Researching life stories: method, theory and analyses in a biographical age. London and New York: RoutledgeFalmer.

Hoskins, C. M., \& Goldberg, A. D. (2005). Doctoral student persistence in counselor education programs: Student-program match. Counselor Education and Supervision, 44(3), 175-188.

Kvale, S. (1996). Interviews: an introduction to qualitative research interviewing. Thousand Oaks, CA: Sage.

Labaree, D. F. (2003). The peculiar problems of preparing educational researchers. Educational researcher, 32(4), 13-22.

Li, Y. (2014). The effect of doctoral study of education on Ph.D. graduates' academic career. Proceeding of Aktuální problémy pedagogiky ve výzkumech studentů DSP". (In print)

Lovitts, B. E. (2004). Research on the structure and process of graduate education: retaining students. In Wulff D. H. \& Austin A. E. (Ed.), Paths to the professoriate: strategies for enriching the preparation of future faculty. pp. 115-136. San Francisco: Jossey-Bass.

Malaney, G. D. (1988). Graduate education as an area of research in the field of higher education. In Smart J. C. (Ed.), Higher education: handbook of theory and research, Vol. VI, pp. 397-454. New York: Agathon.

Mullins, G. \& Kiley, M. (2002). 'It's a Ph.D., not a Nobel Prize': how experienced examiners assess research theses. Studies in higher education. 27(4): 369-386.

Pidgeon, N. \& Henwood, K. (2004). Grounded theory. In Hardy, M. \& Bryman, A. Handbook of data analysis. pp. 625-648. London: SAGE Publications.

Richardson, V. (2003). The Ph.D. in education. Carnegie essays on the doctorate. Menlo Park, CA.

Scheerens, J. (1990). School effectiveness research and the development of process indicators of school functioning. School effectiveness and school improvement, 1(1), 61-80.

Schoenfeld, A. H. (1999). Looking towards the $21^{\text {st }}$ century: challenges of educational theory and practice. Educational Researcher, 28(7), 4-14.

Spqulding, L. S. \& Rockinson-Szapkiw, A. J. (2012). Hearing their voices: factors doctoral candidates attribute to their persistence. International Journal of Doctoral Studies, 7, 199-219.

Staton, A. Q. \& Darling, A. L. (1989). Socialization of teaching assistants. In Nyuqist J. D. \& Aboott, R. D. \& Wulff, D. H. (Eds.), Teaching assistant training in the 1990s. pp. 15-22. San Francisco: JosseyBass. 
Strauss, A. \& Corbin, J. (1990). Basics of qualitative research: grounded theory procedures and techniques. London: SAGE Publications.

Strauss, A. \& Corbin, J. (1998). Basics of qualitative research: grounded theory procedures and techniques ( $2^{\text {nd }}$. Ed.). Thousand Oaks, CA: SAGE.

Van Maanen, J. (1983). Doing new things in old ways: the chains of socialization. In Bess J. L. (Ed.), College and University organization: insights from the behavioral sciences. New York: New York University Press.

Weidman, J. C. \& Twale, D. J. \& Stein, E. L. (2001). Socialization of graduate and professional students in higher education: a perilous passage? ASHE-ERIC higher education report, 28(3). San Francisco: Jossey-Bass.

Wengraf, T. (2001). Qualitative research interviewing. London: SAGE Publications.

West, I. J., Gokalp, G., Edlyn, V., Fischer, L., \& Gupton, J. (2011). Exploring effective support practices for doctoral students' degree completion. College Student Journal, 45(2), 310-323.

Wulff, D. H. \& Austin, A. E. (Eds.) (2004). Paths to the professoriate: strategies for enriching the preparation of future faculty. San Francisco: Jossey-Bass.

The contribution was written by the support of IGA (Studentské grantové soutěže Univerzity Palackého v Olomouci) Funds. Project Name: Research on Quality Evaluation of Ph.D. Studies in Education - Practice in Palacký UniversityPalacký University Olomouc. Project Number: PdF-2013-014.

\section{Contact:}

Mgr. Yanyan Li

doc. PhDr. Jana Poláchová Vaštatková

Institute of Education and Social Studies

Faculty of Education, Palacký University

Žižkovo nám. 5

77140 Olomouc

E-mail: liyanyan.up@gmail.com; jana.polachova@upol.cz 